\title{
Zieleń tódzkich Bałut. Kompozycja przestrzenna miejsc pamięci
} Greenery of the bałuty area in Łódź.
Spatial composition of memory space

\begin{abstract}
Streszczenie
Karol Borowiecki, Maks Baum i Moryc Welt - Polak, Niemiec i Żyd, czyli bohaterowie "Ziemi Obiecanej” - ucieleśniają nawarstwienie kultur, jakie tworzyły Łódź już od XVIII wieku. Obecnie miasto stawia czoło tematom przywracania pamięci o dawnych mieszkańcach. Coroczny Festiwal Dialogu Czterech Kultur, rewitalizacja miejsc zagłady, czy tworzenie nowych przestrzeni pamięci jak Park Ocalonych, Park im. Szarych Szeregów to tylko kilka spośród działań nawiązujących dialog z przeszłością, aktywizujących przestrzeń współczesną. W krajobrazie Bałut, jednej z dzielnic Łodzi, widać połączenie niespełnionego snu o rewolucji urbanistycznej i przebłysków minionej tożsamości miasta Litzmannstadt, które stwarza szansę przestrzeniom zielonym, by stały się ich spoiwem. Autorka bada zależność między miejscami pamięci, a przestrzeniami zielonymi w krajobrazie Bałut pod kątem kompozycji jako narzędzia narracyjnego w przestrzeni.
\end{abstract}

\begin{abstract}
Karol Borowiecki, Maks Baum and Moryc Welt - a Pole, a German and a Jew - the heroes of "The Promised Land" - embody the layering of cultures that have been forming Łódź already since the eighteenth century. The city is currently facing subjects of restoring the memory of its past inhabitants. The yearly Łódź of Four Cultures Festival, the revitalisation of sites of genocide or the establishment of new memorial sites like Survivors' Park and Grey Ranks Park are but a few of the efforts that initiate dialogue with the past and that activate contemporary space. In the landscape of Bałuty, one of the districts of Łódź, we can see a combination of the unrealised dream of an urban planning revolution and glimpses of the past identity of the city of Litzmannstadt, which gives a chance for green areas to become their binding element. The author studied the dependency between memorial sites and green spaces in the landscape of Bałuty in terms of composition as a narrative tool within space.
\end{abstract}

Słowa kluczowe: kompozycja, zieleń, Łódź, Bałuty, pamięć, ekspresja, dialog Keywords: composition, greenery, Łódź, Bałuty, memory, expression, dialogue

Łódź, jako dawne miasto czterech kultur - polskiej, żydowskiej, niemieckiej, rosyjskiej - podzielone trudnym splotem zdarzeń, ma wiele historii, które odkrywa na nowo, w poszukiwaniu dawnej tożsamości. Nieraz, owym poszukiwaniom towarzyszą tereny zielone. Park Staromiejski z Pomnikiem Dekalogu, Park Ocalałych z pomnikiem Sprawiedliwych wśród Narodów Świata i Kopcem Karskiego, Centrum Dialogu im. Marka Edelmana, Park im. Szarych Szeregów z pomnikiem Martyrologii Dzieci, Nowy Cmentarz Żydowski, Stacja Radegast - to kilka z „zielonych” miejsc pamięci na terenie dzisiejszych Bałut obszaru szczególnie doświadczonego historią.

Ta dzielnica w północnej części miasta, choć nie uwodzi architekturą, nie zaprasza w przyjazne miejsca publiczne, ani nie czaruje atrakcjami, jest obszarem intrygującym i pełnym treści. Obszarem, który boryka się zarówno z problemem przestrzeni zaniedbanych i opuszczonych (można spotkać pustostany, wybite okna, niedziałające już lokale usługowe), ale także z trudną historią - tu, w latach 1940-1944 było getto. $Z$ jednej strony odpycha jako miejsce niebezpieczne, a drugiej przyciąga terenami zielonymi, które jednocześnie opowiadają historię miasta.
Łódź, as a former city of four cultures - Polish, Jewish, German and Russian - divided by a difficult course of events, has many histories that it discovers anew in search of its past identity. These pursuits are often accompanied by green areas. Staromiejski Park with the Decalogue Monument, Survivors' Park with the Monument of the Righteous Among the Nations, and the Mound of Karski, the Marek Edelman Centre of Dialogue, Grey Ranks Park with the Children's Martyrology Monument, the New Jewish Cemetery, Radegast Station - are only a few of the "green" memorial spaces in the area of contemporary Bałuty - an area that has had a particularly difficult history. This district in the northern part of the city-although it does not seduce us with its architecture, invite us into friendly public places, nor does it charm us with attractions - is a place that is intriguing and full of narratives. An area that is troubled by the problem of neglected and abandoned spaces (we can find abandoned buildings, broken windows and vacant premises here), but also with a difficult history - in the years 1940-1944 it was the site of a ghetto. On the one hand it repulses us as a dangerous place, while on the other it attracts us with green areas, which simultaneously narrate the history of the city. 


\section{BAEUTY HISTORYCZNE}

Już na początku XV wieku można zauważyć w literaturze wzmianki o wsi Bałuty, jako części dominium Radogoszcz. Zespół ten znajdował sie na drodze traktu piotrkowskiego, łaczącego Włocławek ze Zgierzem.

W XIXw w Łodzi rozwija się przemysł włókienniczy. Miasto powiększa swoje terytorium ponad dwukrotnie, lecz Łodzi wciąż grozi przeludnienie. 1 Jako obszar dobrze skomunikowany $i$ atrakcyiny dla ludności naptywowej, Baluty staja sie najwieksza wsia w Europie. Stan ten trwa aż do roku 1915 gdy po wi wo mieść do todzi Batuty zost

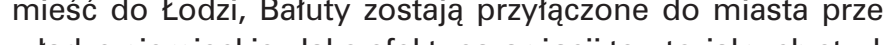
tura dróg diametralnie się zmienia, co przyczynia się do ekotura dróg diametralnie się zmienia, co przyczyna
nomicznego i społecznego awansu obszaru. ${ }^{2}$

Od kwietnia 1940 r. do sierpnia 1944 r.na terenie części BaOd kwethe lut i Starego Miasta zlokalzowane by getto Litzmannstadt - pierwsze odizolowane getto na terenie okupowanej Polski. Wybrano tereny najbardziej zaniedbane, z najgorzej rozwinięprzez ludność ubogą, a także $w$ dużej części przez żydów. przez ludność ubogą, a także w dużej części przez Zydów. W latach pięćdziesiątych władze socjalistyczne planowały dokonać przeprojektowania obszaru Bałut, tworząc z zaniedbanego, opuszczonego po wojnie terenu imponującą dzielnice robotniczą. Autorem planu był Ryszard Karłowicz wraz z zespołem pracowni ZOR ${ }^{3}$, a dalszymi uzupełnieniami kierowal Bolesław Tatarkiewicz wraz z pracownią Miastoprojekt. Docelowo plan był przeznaczony dla 40 tysięcy mieszkańców zgromadzonych w sześciu niezależnych osiedlach - każde z nich miało mieć zapewnione usługi, szkołę, przedszkole etc. Przewidziane były również dwa obszary reprezentacyjne - Rynek Starego Miasta - który częściowo został zrealizowany - oraz Rynek Bałucki, do realizacji którego nigdy nie doszło. ${ }^{4}$ Istotną rolę $\mathrm{w}$ planie odgrywały także tereny zielone - zarówno na obszarze każdego osiedla przewidziane były parki, jak i w skali całego założenia - zielone szwy od strony południowej i północnej. Z powodu zmiany władzy i niedoborów finansowych jedynie dwa obszary zostały cześcio zrealizowane - osiedle staromiejsce w okolicy Starego Rynku, a także zespół Bałuty I.

W roku 1954 Bałuty stały sie jedna z 7 dzielnic administracyjnych Łodzi, która $w$ dalszych latach zostaje powiększona. W 1993r podział na tódzkie dzielnice zostaje zniesiony, lecz w świadomości mieszkańców, Bałuty wciąż jawią się jako określony obszar o charakterystycznej tożsamości.

\section{BAtUTY WSPÓŁCZESNE}

Bez kija i noża nie podchodź do Bałuciorza - to popularne powiedzenie, obrazujące $z$ jakimi problemami zarówno w przeszłości, jak i dzisiaj boryka się obszar Bałut. Kojarzy się z przestępczością już od początku XX wieku, gdy narodziły się legendy o Slepym Maksie - legendarnym tódzkim gangsterze. ${ }^{5}$ Bałuty mają więc opinię dzielnicy niepokojącej, zaniedbanej, na której podwórkach rozwija się patologia. Dziś wizerunek ten zdominowany jest przez wojny kibiców klubów piłkarskich: RTS Widzew Łódź i ŁKS Łódź. Niekończące się blokowiska, niedostateczne oświetlenie uliczne, brak usług
1. HISTORICAL BALUTY

Mentions of the village of Bałuty could be found in literature already at the start of the fifteenth This complex was located along the route of the Piotrków trail, which connected Włocławek with Zgierz.

In the nineteenth century Łódź was the site of the development of the textile industry. The city
expanded its territory over twofold, however, it was still under threat from overpopulation 1 . As an area with good circulation and attractive to newcomers, Batuty became the largest village in Europe. This state of affairs would last up to the year 1915, when, after many years of planning the incorporation
of the northern suburbs into tódż, Bałuty were incorporated into the city by German authorities. As an effect of territorial rearrangements, the road structure changed dramatically, which led to the economic and social advancement of the area $^{2}$. From April 1940 to August 1944 a part of Bałuty an ghetto - the first isolated ghetto in occupied Poland. Areas that were the most neglected, with the most poorly developed urban infrastructure (e.g. no sewerage), inhabited by the poor, and als largely by Jews, were selecte

In the 1950 's the socialist authorities planned to was neglected and abandoned after the war into an impressive workers' district. The author of the plan was Ryszar Karłowicz, along with the design supplementations of the design were wive further Bolestaw Tatarkiewicz along with the Miastoprojekt

design office.
The plan was ultimately meant for 40 thousand residents gathered into six independent housing estates - each of which was to be provided
with services, a school, a kindergarten, etc. Two representative areas were also featured - the Old Town Market Square - which was partially built and the Bałuty Market Squaure, which was never built 4 Green areas also played an essential role in the plan - the areas of each of the districts feature titches from the southern and norther side. Due to the change in government and financial shortages, only two areas were partially built -th Osiedle Staromiejskie housing estate near the Old In 1945 Batuty became one of the seve administrative districts of Łódź, which was expanded during later years. In 1993 the division into Łódż's districts was abolished, however, in the minds of the residents Bałuty are still seen a

2. CONTEMPORARY BAEUTY

Bez kija i noza nie podchodz do Bałuciorza (roughly translated as don't approach a local from Bafuty Willustrating the and a knife) - is a popular saying faced in the past, as well as the ones that it faces today. It was associated with crime already at the start of the twentieth century, when the legend about Blind Max - a legendary Łódź gangster were first born'. Bałuty thus have an opinion of an home to a developing social pathology. This image is dominated by the clashes of football hooligan
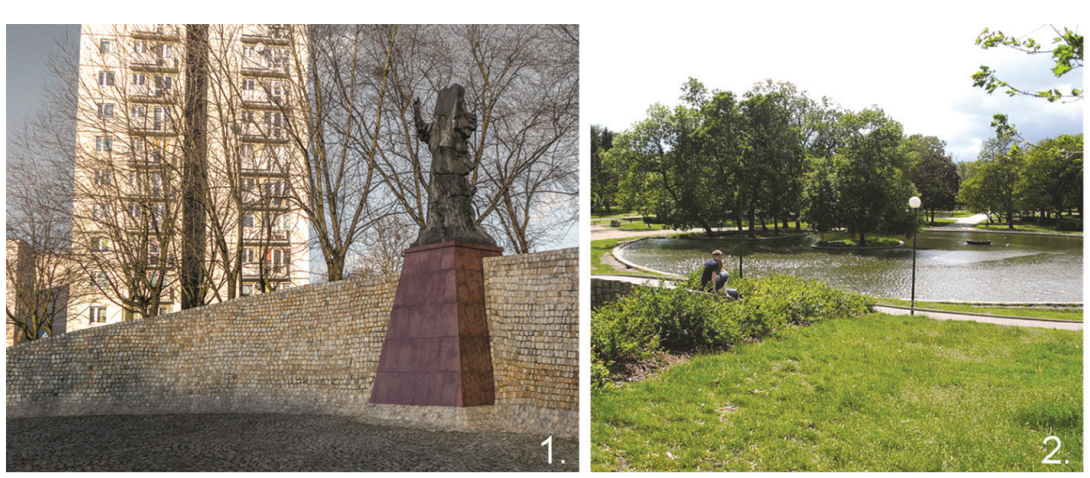

?

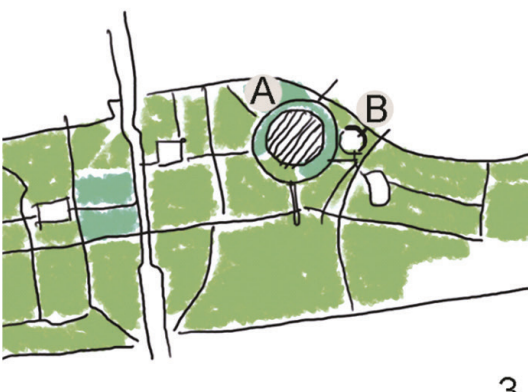

$1-3$

i kulturalnego życia nocnego wpływają na postrzeganie dzielnicy jako niebezpiecznej.

[...] patologia widzę to co dnia , za zbrodnią zbrodnia, [...],bafucka krew płynie w moich żyłach, [...], wieczne pole bitwy. dzielnica dwóch klubów [...]

[...] Zawód-jubiler, hobby-diller, Tak ptynie bałucki thriller [.... $]^{7}$ To tylko fragmenty $z$ twórczości popularnych raperów jak O.S.T.R czy Beron, którzy obrazują Bałuty jako przestrzeń kryminogenną, ale także wyrażają swoje przywiązanie - dając dowód na utworzenie się lokalnej tożsamości miejsca.

Na budynkach pojawiają się graffiti $w$ dowcipny sposób wchodzące $w$ dyskurs charakterystyczny dla napisów na murach, np. „LKS spi w skarpetkach", co dowodzi,że społecznosć bałucka charakteryzuje się wysoką świadomoscią własnej tożsamości i eksploatuje ją w wesoly sposob. Profil na portalu społecznościowym Facebook - Bałuty ${ }^{9}$, przy pomocy artystycznych zdjęc i filmów prezentuje codzienną przestrzen miejską Bałut. Profil obserwuje 12,5 tys uzytkowników portalu, zatem pomimo szorstkiego charakteru tego miejsca, odbiorcy chętnie poszukują w nim poetyckiego genius loci. Bałuty, jako obszar dawnego getta, był terenem koniecznym do ponownego zagospodarowania nie tylko w wymiarze nowego planu urbanistycznego. Bałuty wymagaja też nowej narracji, perspektywy zmianym która pozwoli na zrozumienie przeszłości i utworzy pomost ze wspótczesnościa. Potwierdzeniem owej potrzeby jest działalność indywidua nych

IL. 4-6
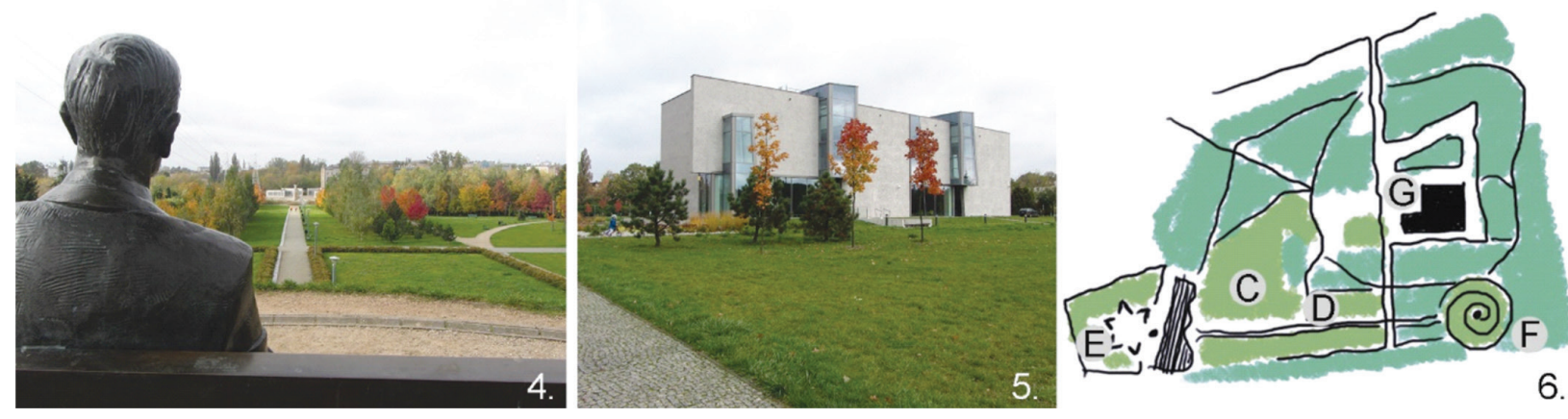

supporting the RTS Widzew tódź and ŁKS Łódż culture-related nightlife affect the perception of the district as a dangerous place.

pathology I see this every day crime after crime, $[. . .$, Batuty blood runs through my veins, [... an eternal field of battle, a district of two clubs $[. . .]^{6}$

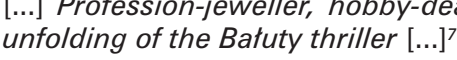
as a criminogenic space, but also express the attachment - providing proof of the formation of local identity of the area.

Graffiti which humorously engages in discourse characteristic of writings on walls appears on
the buildings, like "tKS sleeps in their socks" which proves that the community of Bałuty is characterised by a high awareness of its own The $B$ and makes use of it in a joyous manner. website, through the use of artistic photographs and films, presents the everyday urban space of Bałuty. The profile is observed by 12,5 thousand users of he website, which means that despite the searches for a poetic genius loci within it.

Batuty, as the site of the former ghetto, was an area solely to the dimension of a new urban plan. Bałuty also require a new narrative, a perspective football clubs. The unending panel block estates,

These are but fragments of the works of popular for change that will allow it to understand the past 
dynków na terenie Bałut powstały murale z autentycznymi wzorowanych na archiwalnych zdjęciach. ${ }^{10}$ Dzięki instalacjom artystycznym Anki Leśniak na opuszczonych budynkach przywrócona została pamięć na temat kobiet ważnych dla historii Łodzi (Michalina Zuch dziewczyna oraz Fifi Zastrow.Acta est fabula)."1

Na terenie Bałut zieleń są istotnym nośnikiem pamięci, będące wyciszonym ttem dla pomników i miejsc zadumy, wprowadzając nastroj naznaczonego trudną historią.

\section{PARK STAROMIEJSKI}

Park Staromiejski ${ }^{12}$ znajduje się w południowej cześci Bałut, pomiedzy ulicami Północną i Zachodnia. Przed wojną znajdowała się tutaj synagoga wielka tzw. Altstedt, targ rybny i zabudowa, która w większości zamieszkiwała ludność żydowska. Część zabudowy uległa zniszczeniu lub wyburzeniu podczas wojny, by wyraźnie zarysować i odizolować południową ścianę getta. Po wojnie zdecydowano, by ten teren zaaranżować jako park. Jego dominującym elementem jest zbiornik wodny o kształcie okręgu na miejscu dawnej Altstedt (il. 3,A). Tuż obok znajduje się kolejny okrag - skwer z Pomnikiem Deka$\operatorname{logu}^{13} \mathrm{~W}$ formie półkolistego, wznoszącego się muru $\mathrm{z}$ figurą Mojżesza (il.3,B). W zależności od definicji, można zastanawiać się, czy jest to miejsce pamięci'14. Jednak przywołanie dekalogu, jako symbolu występującego zarówno w kulturze chrześcijanskiej (Dziesięć Przykazań), jak i żydowskiej (Dziesięć Oświadczeń) daje pole dialogu i przywracania dawnej todzkiej tożsamości. Park Staromiejski jest początkiem zielonego szlaku Bałut.

\section{PARK OCALAKYCH}

Jesteśmy starymi drzewami,

Głęboko i szeroko wrośniętymi w ziemię,

Owielkich koronach, które zdobią świat. ${ }^{15}$

Pisał Rachmund Bryks w wierszu "Nie trać nadziei", który stał się inspiracją dla Haliny Elczewskiej - pomysłodawczyni sadzenia drzew w Parku Ocalałych. Autorką koncepcji parku jest architektka krajobrazu Grażyna Ojrzyńska, a autorką projektu - Monika Michnowska.

W ciągu 12 lat od roku 2004 ponad 500 Ocalałych z tódzkiego getta zostawito tu swoją sadzonkę Drzewa Pamięci'16 (il. 6,C). Ich nazwiska widoczne są zarówno przy drzewie, jak i na pomniku w formie imiennych tablic ciągnayych się $w$ posadzce wzdłuż głównej osi założenia (il.6,D). Aleja Arnolda Mostowicza łączy dwa dominujące elementy kompozycji: Pomnik Sprawiedriwych Wsod Nacodow Swiata (E) i Kopiec Karskiego (il.6,F). ${ }^{17}$ Pomnik Sprawiedliwych... autorstwa Czesława Bieleckiego znajduje się w zachodniej częśsci Parku, stanowiąc kontynuacje zielonego szwu Bałut, (od Parku Staromiejskiego przez Park Helenów). Pomnik tworzą sciany z tablicami z nazwiskami osób, które zaangażonane były w pomoc ofiarom zagłady. Z lotu ptaka sciany przybierają formę przetworzone Gwiazdy Dawida - powszechnie rozpoznawalnego symbolu judaizmu. Jedno $z$ ramion zostaje zastąpione postumentem z orłem, wskazującym kierunek ku głównej alei. activity of individual artists is a confirmation of this need. Thanks to Kataryna Tosta's idea, hie wals of the buildings in the Bałuty area were covere children of many cultures from the pers of loca occupation, modelled after archival photographs ${ }^{1}$. Thanks to the artistic installations of Anka Leśniak on the abandoned buildings, the memory of women important to the history of Łódź has bee Fifi Zastrow.Acta est fabula) 11

Greenery is an essential conveyor of remembrance in Batuty, constituting a quiet background for monuments and memorial sites, introducing an atmosphere of sacrum in an

\section{STAROMIEJSKI PARK}

Staromiejski Park ${ }^{12}$ is located in the southern part of Bałuty, between Północna and Zachodnia Street. the so-called Altstedt, a fish market and building which were mostly inhabited by Jews. A portion of the buildings was destroyed or demolished durin the war, in order to clearly demarcate and isolate the southern wall of the ghetto. After the war a park. Its dominant feature is a water reservoir in the shape of a circle in place of the former Altsted (ill. 3,A). Close by is another circle - a green square with the Decalogue Monument ${ }^{13}$ in the form of a semicircular, rising wall with a statue of up for discussion whether it is a memorial site However, making a reference to the Decalogue a a symbol that is present in Christian culture (the Ten Commandments), as well as in Jewish culture (the Ten Sayings), provides a space for dialogue Park is the start of the green trail of Batuty.

\section{SURVIVORS' PARK}

We are old trees,

Rooted deeply and broadly in the earth,

So wrote Rachmil Bryks in his poem

lose hope", Halina Elczewska - the originator of the idea of planting trees in Survivors' Park. The author of th conceptual design of the park was the landscap design was Monika Michnowska. Over the course of 12 years since 2004, over
500 Survivors of the tódź ghetto have left their 500 Survivors of the kódź ghetto have left their
seedlings of Memorial Trees ${ }^{16}$ here (ill. 6, C). Their seedlings of Memorial Trees 16 here (ill. 6, C). Their
names are visible near each tree, as well as on names are visible near each tree, as well as on
a monument in the form of named plaques that run in the paved surface along the main axis of the layout (ill. 6, D). Arnold Mostowicz Avenue connects
two dominant elements of the composition: the two dominant elements of the composition: the
Monument to the Righteous Among the Nations (E) and the Mound of Karski (ill. 6 , F) ${ }^{17}$. The Monumen of the Righteous Among the Nations by Czestaw
Bielecki is located in the western part of the Park forming a continuation of the green stitch of Bałuty (from Staromiejski Park through Helenów Park). The monument is composed of walls featuring plaque containing the names of people who were involve in aiding genocide victims. From a birds-eye view
the walls take on the form of an altered Star of David - a widely accepted symbol of Judaism. One of
Wzdłuż Alei Mostowicza wciąż przybywa Drzew Pamięci. Saparku. Na jejzakońnczeniu widnieje zielony kopiec o wysokości 8,5 m dedykowany Janowi Karskiemu - polskiemu kurierowi który wiadomości o holokauście i potrzebie niesienia pomocy dostarczał do władz USA i Wielkiej Brytanii. Na szczycie kopca znajduje się pomnik Karskiego w formie mosieżnej postaci siedzacej na ławce, spogladajacej w kierunku Pomnika Sprawiedliwych, podkreślając osiowość założenia.

W pótnochej czésci parku znajduje sie Centrum Dialogu im. pón chalogu im.

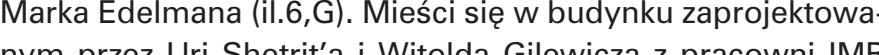
I Asymetra - szkła, betonu i kamienia. Spoista, pokryta kamieniem bryła poprzecinana szklanymi formami balansuje na granicy harmonii i niepokoju. Laczy w sobie przeciweñstwa i rozmaite połączenie nieraz przeciwnych sobie podmiotów.

\section{PARK IM. SZARYCH SZEREGÓW}

Park im. Szarych Szeregów znajduje się ok. 500m na północ od Parku Ocalałych. Tu, w latach '60tych wyburzono znaczną część zabudowy i zazieleniono obszar. To kolejne miejsce Bałut, gdzie pamięc o wydarzeniach związanych ze smiercia celebruje się roślinnością - symbolem życia. Park jest jednoczesnie początkiem Szlaku pamięci ofiar hitlerowskiego ludobójstwa ${ }^{20}$ na terenie obecnego województwa łódzkiego.

Teren jest wyraźnie podzielony na trzy równoległe części przecięte ciągami komunikacyjnymi - ulicą Tadeusza Boya -Żeleńskiego i traktem pieszym, będącym kontynuacją ulicy Brackiej. Ten ostatni stanowi spacerowa oś kompozycyjna będącą jednocześnie monumentalnym założeniem pomnikowym z szeroką kaskadą schodów, ponad wrzecionowatym skwerem. Na szczycie schodów w alei spacerowej znajduje sie Pomnik Martyrologii Dzieci „Pęknietego Serca” (il. $9, \mathrm{H}$ ) autorstwa Jadwigi Janus i Ludwika Mackiewicza, poświeco au dziciom zamordowany w tzw. Prewencyiny poświęcoPolici Bezpieczeńs Przemys o dziecka które-widziane od tylu - opiera sie o skonego dzreck, ktore - widzin pred od tyu - opiera sie o skorupe stać dziecka jest negatywowo wycięta. Pomnikowi towarzy- the arms was replaced with a plinth with an eagle, pointing waw reds the direction of the main avenue, More and more Memorial Trees are still being (t) of the park. At its culmination is a green mound with a height of 8,5 metres, dedicated to Jan Karsk a Polish courier, who delivered information about the Holocaust and the need for aid to the op of the mound is a monument to Karski in the form of a brass figure sitting on a bench, looking in the direction of the Monument of the Righteous, highlighting the axial character of the layout. ( designed by Uti Shetrit and Witold Gilewicz of the IMB Asymetria ${ }^{18}$ design company. The building appears to be made out of layers - glass, concrete and stone. The compact, stone-covered massing cut by glass forms balances on the line between and various forms, highlighting the message tha conveys - dialogue, and thus a combination of often mutually opposing entities ${ }^{19}$.

\section{GREY RANKS PARK}

Grey Ranks Park is located around 500 metres to the north of Survivors' Park. A significant part of the area's buildings were demolished in the 1960's and place in Batuty where memory of events associated with death is celebrated through greenery a symbol of life. The park is simultaneously the start of the Memorial trail of Nazi genocide ${ }^{20}$ in the The area is clearly divided into three paralle sections, crossed by circulation trails - Tadeusza Boya-Zeleńskiego Street and a pedestrian route
which constitutes a continuation of Bracka Street. The latter forms a walking compositional axis, whic is simultaneously a grand monument complex with a broad cascade of stairs above a spindle-shaped green square. At the top of the stairs is the "Broken by Jadwiga Janus and Ludwik Mackiewicz, devoted to the memory of children murdered at the so-called Preventative Security Police Camp for Polish youth in todz near Przemystowa Street ${ }^{2}$. The sculpture depicts the emaciated frame of a child, which immense form which resembles a broken heart

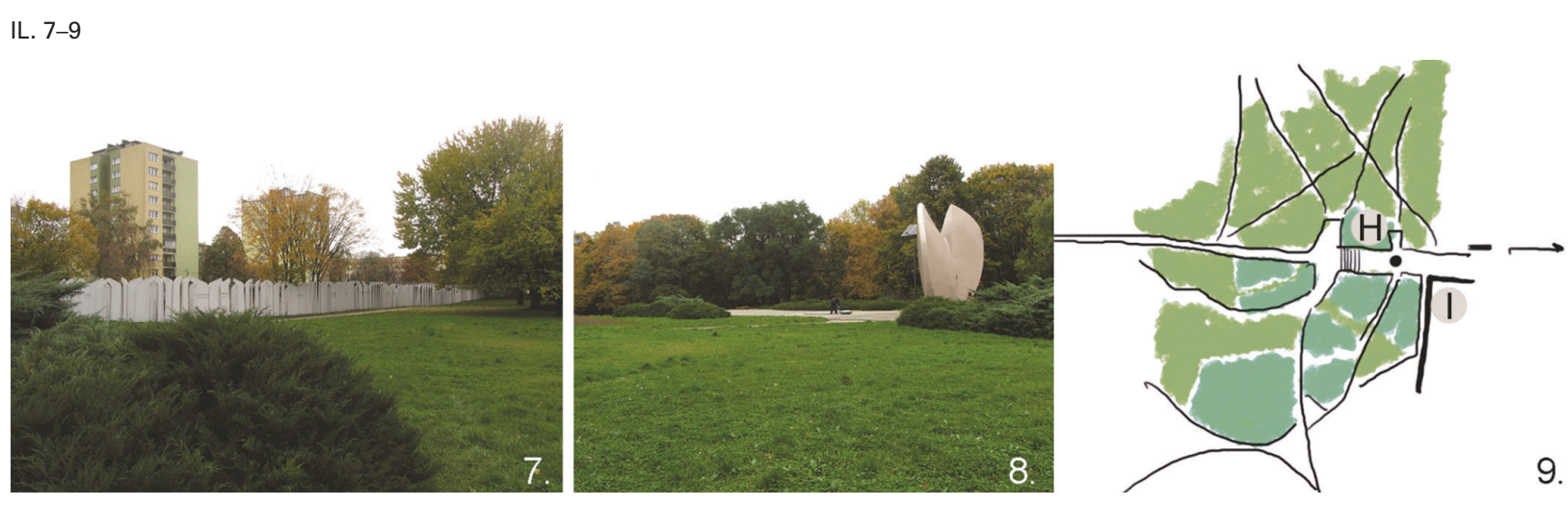


szy pamiątkowa tablica w posadzce. Kompozycja wywiera tym mocniejsze wrażenie, gdyż widziana na tle zieleni, stanowi jedyną dominantę

U wyjścia z parku, na początku ulicy Brackiej, znajduje się dalsza część pomnika: część niefiguratywna, mniej dosłowna. Fragment ogrodzenia sasiedniej działki zastapiony jest murem kamiennych tablic, charakterystycznie zaostrzonych w górnej partii, symbolizuiąc ściane prewencyinego obozu dzieciecego (il. 9,l). Niektóre płyty nosza na sobie wyryte nazwy obozów zagtady zc - skupione w krótkich liniach - umieszczone sa jackiej płyty ku miejscach przedluziac linie oddziatywania pomnika-drogi, a takie prowadzac wzok obserwatora w dal, na wschod. gi, a takze prowadzazc wzrok obserwá zu dziecięcego.

\section{NOWY CMENTARZ ŻYDOWSK}

Podazżając za tablicami Pomnika Martyrologii Dzieci, przez ulicę Bracką dociera się do dawnego wejścia Nowego Cmentarza Zydowskiego - największej obszarowo europejskiej nekropolii żydowskiej.22 Dominującą zasadą kompozycyjną na tym obszarze jest główna os spacerowa, wzdłóż której można zauważyć nagromadzenie macew (il.12,J). Oś zapoczątkowana jest wejściem głównym od strony ulicy Zmiennej, któremu towarzyszą budynki m.in. łaźni i domu przedpogrzebowego (il. $12, \mathrm{~K}) .{ }^{23}$

Niezwykły charakter tego miejsca wynika z obrzędowości żydowskiej i traktowania grobu zmarlego, jako materii nienaruszalnej. W przeciwieństwie do opieki nad cmentarzem chrześcijańskim - na grobach żydowskich nie ma żadnych widocznych dowodów na to, że zostały odwiedzone ${ }^{24}$. Rzeźbione, kamienne płyty nagrobne, pokryte mchem, stają się jednością z otaczającą zielenią. Groby oddalone od głównej alei wydaja sie wnikać wgłąb masy dzikich drzew i krzewów. Przenikanie sie materii naturalnej $i$ tej, spod reki człowieka, daje w tym miejscu niezwykły charakt starannie zaaranżowanego Parku Ocalonych.

\section{STACJA RADEGAST}

Kolejnym przystankiem na szlaku miejsc pamięci Bałut jest Stacja Radegast z Muzeum i Mauzoleum na Radogoszczu ${ }^{25}$

Stacja Radegast powstała w 1925 roku, jako połączenie kole- and from which the figure of the child is cut out as if in a negative. The monument is accompanied by a memorial plaque in the paved surface.
The composition makes an even more striking impression as it is seen against the background of greenery, constituting the sole landmark. At the exit from the park, at the start of Bracka Street, there is the second part of the monumen - a non-figurative, less explicit part. A fragment of a wall made out of stone tablets, characteristically sharpened in their upper part, symbolising the wal of the preventative children's camp (ill. 9, I). Some of the tablets bear inscriptions of the names of death camps from all over Poland. Along the length of - are placed in a number of spots, extending the line of impact of the monument-path, in addition to leading the observer's vision towards the horizon, to the east. The placement of the tablets is meant to

\section{NEW JEWISH CEMETERY}

Following the tablets of the Children's Martyrology Monument, along Bracka Street, we arrive at the former entrance to the New Jewish Cemetery - the The dominant compositional principle in this area is the main pedestrian axis, along which we can find an accumulation of matzevot (ill. 12, J). The axis starts at the main entrance from Zmienna Street, which is accompanied by the buildings of, among others, the

a result of Jewish ritual and treating the grave is a deceased person as inviolate matter. Contrary to care for a Christian cemetery - on Jewish graves there are no visible signs of anyone's visits become one with the surrounding greenery. The graves located further away from the main avenue appear to blend into the mass of wild trees and bushes. The blending of natural matter and tha which has come from under a man's hand gives contemplation - the opposite of the meticus and arranged Survivors' Park.

7. RADEGAST STATION

Another stop on the trail of Batuty's memoria Mausoleum in Radogoszcz 25.
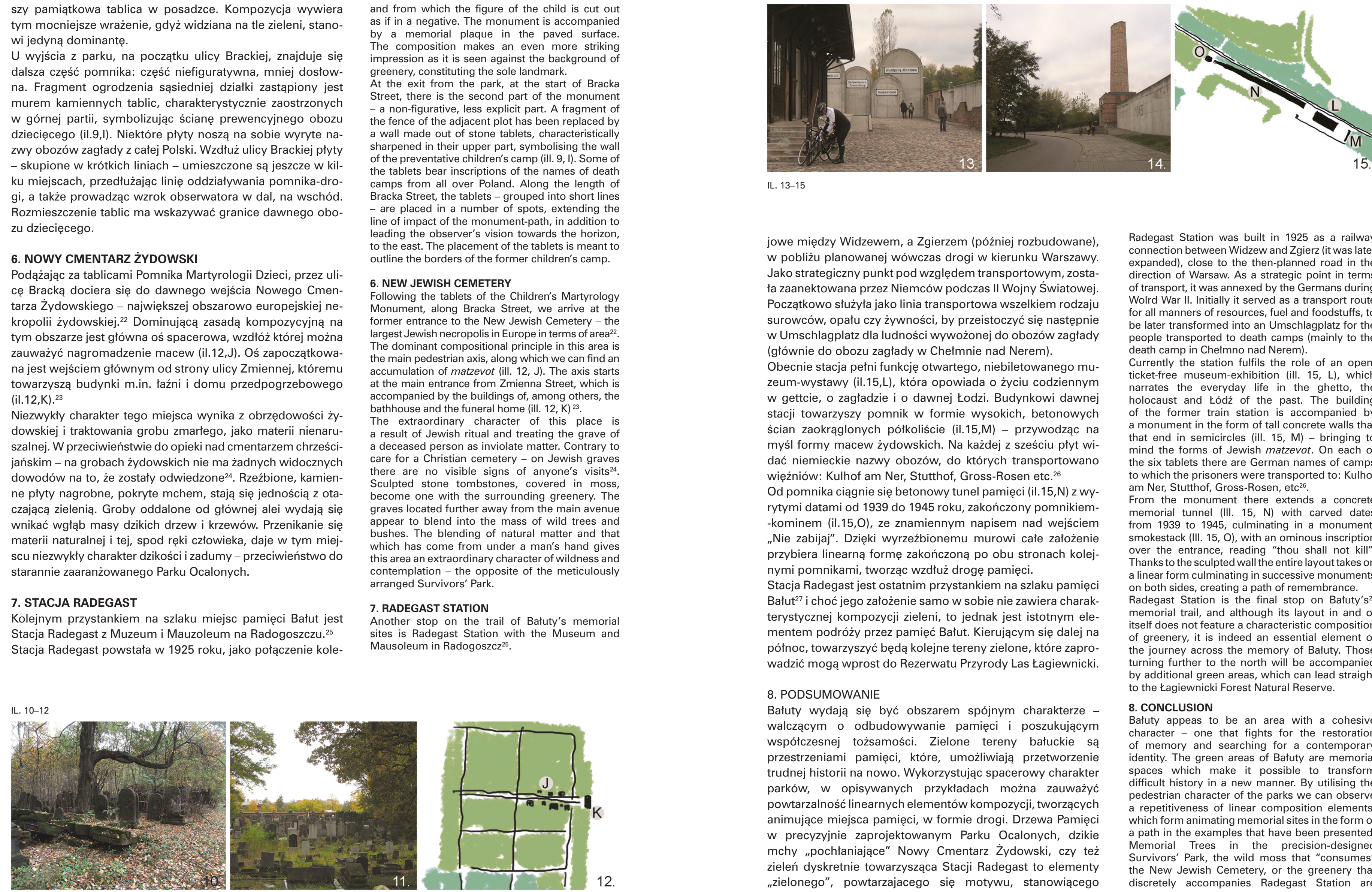

LL. 13-15

jowe między Widzewem, a Zgierzem (później rozbudowane) w pobliżu planowanej wówczas drogi w kierunku Warszawy. Jako strategiczny punkt pod wzgle dem transportowym, zostata zaanektowana przez Niemców podczas II Wojny Światowej Początkowo służyła jako linia transportowa wszelkiem rodzaju surowców, opału czy żywności, by przeistoczyć się następnie w Umschlagplatz dla ludności wywożonej do obozów zagłady (głównie do obozu zagłady w Chełmnie nad Nerem).

Obecnie stacja pełni funkcję otwartego, niebiletowanego muzeum-wystawy (il.15,L), która opowiada o życiu codziennym w gettcie, o zagładzie i o dawnej Łodzi. Budynkowi dawnej stacji towarzyszy pomnik w formie wysokich, betonowych scian zaokrąglonych półkoliscie (ii.15,M) - przywodząc na myśl formy macew zydowskich. Na każdej z sześciu płyt widac niemieckie nazwy obozów, do ktorych transportowano więźniów: Kulhof am Ner, Stutthof, Gross-Rosen etc.

Od pomnika ciągnie się betonowy tunel pamięci (il.15,N) z wyrytymi datami od 1939 do 1945 roku, zakończony pomnikiem-kominem (il.15,0), ze znamiennym napisem nad wejściem "Nie zabijaj”. Dzięki wyrzeźbionemu murowi całe założenie przybiera linearną formę zakończoną po obu stronach kolenymi pomnikami, tworzac wzdłuż droge pamięci.

Stacja Radegast jest ostatnim przystankiem na szlaku pamiẹci Bałut27 i choć jego założenie samo w sobie nie zawiera charakerystycznej kompozycii zieleni, to jednak jest istotnym elementem podróży przez pamieć Ba jut. Kierujacym sie dam elepón y Las Łagiewnicki.

\section{PODSUMOWANIE}

Bałuty wydaja się być obszarem spóinym charakterze walczącym o odbudowywanie pamięci i poszukującym współczesnej tożsamości. Zielone tereny bałuckie sa przestrzeniami pamięci, które, umożliwiają przetworzenie rudnej historii na nowo. Wykorzystujac spacerowy charakter parków w opisywanych przykładach można zauważy parkow, w opisywanych przykladach można zauważyć powtarzalnośc linearnych elementów kompozycji, tworzących
animujące miejsca pamięci, w formie drogi. Drzewa Pamięc w precyzyjnie zaprojektowanym Parku Ocalonych, dzikie mchy "pochłaniające "Nowy Cmentarz Zydowski, czy też zieleń dyskretnie towarzysząca Stacji Radegast to elementy "zielonego", powtarzajacego się motywu, stanowiącego
Radegast Station was built in 1925 as a railway connection between Widzew and Zgierz (it was late expanded), close to the then-planned road in the fortion of Whrsaw. As a strategic point in terms Wolrd War II. Initially it served as a transport rout or all manners of resources, fuel and foodstuffs, to be later transformed into an Umschlagplatz for the people transported to death camps (

death camp in Cheimno nad Nerem).
Currently the station fulfils the role of an open,
ticket-free museum-exhibition (ill narrates the everyday life in the ghetto, the holocaust and Łódź of the past. The building of the former train station is accompanied by a mind the forms of Jewish matzevot. On each of there are German names of camps to which the prisoners were transported to: Kulhof am Ner, Stutthof, Gross-Rosen, etc ${ }^{22}$.

from the monument there extends a concrete memorial tunnel (III. $15, N$ ) with carved dates
from 1939 to 1945 , culminating in a monumentsmokestack (III. 15, 0), with an ominous inscription over the entrance, reading "thou shall not kill". Thanks to the sculpted wall the entire layout takes on

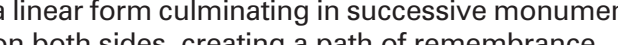
Radegast Station is the final stop on Batuty's $s^{2}$ memorial trail, and although its layout in and of itself does not feature a characteristic composition of greenery, it is indeed an essential element of turning further to the north will be accompanied by additional green areas, which can lead straight to the tagiewnicki Forest Natural Reserve.

\section{CONCLUSION}

Batuty appeas to be an area with a cohesive character - one that fights for the restoration of memory and searching for a contemporary 作 difficult history in a new manner. By utilising the pedestrian character of the parks we can observe a repetitiveness of linear composition elements, which form animating memorial sites in the form of a path in the examples that have been presented. Survivors' Park the wild moss that "consumes" the New Jewish Cemetery, or the greenery that discretely accompanies Radegast Station are 
kojące tło dla traumatycznych treści. Jednocześnie zmystowy charakter zeleni intensywnie wplywa na percepcje odbiorcy, wzbudzając wspomnienia i wyobrażenia, a jak twierdził Juhani Pallasmaa w Oczach skóry:

Percepcja, pamięć i wyobraźnia znajduja się w stanie nieustannej interakcji.

\section{ENDNOTES}

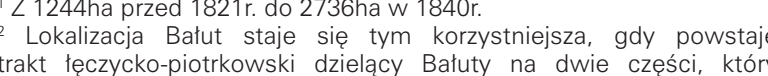
wóńniejszym okresie potaczy siezz ztzw. Traktem fabrycznym, taczacym

Projekt Domu Kultury autorstwa Józefa Zbigniewa Polaka z 1951

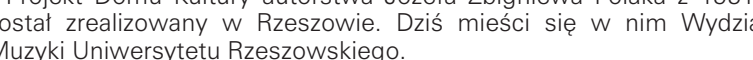
Menachem Bornsztajn, zwany królem dintojy-cywilnego sąd

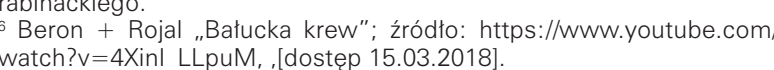

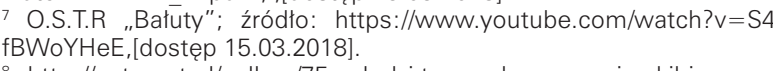

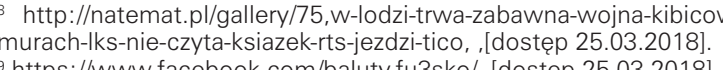

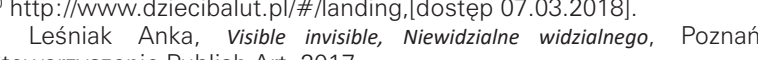
Stowarzyszenie Publish Art, 2017.
12 Autor projektu: Kazimierz Chrabelski. 1953r.

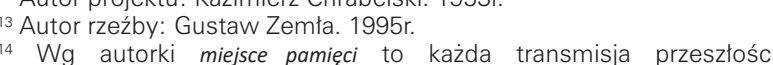

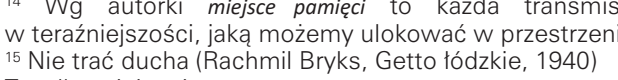

To tylko wieje wiatr-
Nie trać duch moje dziecko

Jesteśmy starymi drzewami,
GGęboko is zreroko wrośietymi w ziem

Silne wiatry burzowe moga nam

Obrywác liścice
Gatezie tamać

Gatezie tamać,
Ale nie korony!

Mocnych, gleboko wrośniettych drzew

Ani wykorzenić!

Jesteśmy drzewami wiecznymi,
Dajacymi swiatu pożyne owoce.

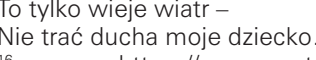

htps://Www.centrumdialogu. com/park-ocalalych/biogramy
ccalalych [dostęp 07.02.2018]. https: //www.centrumdialogu.com/park-ocalalych [dostęp o7.02.2018.

[dostep 05.002.2018].
hathy

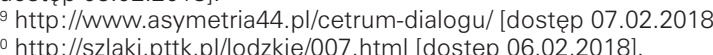

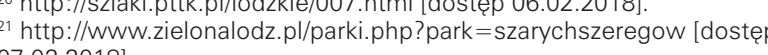

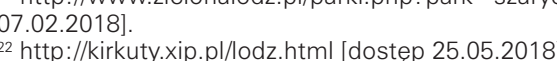

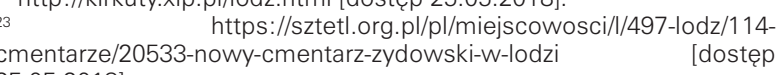
${ }^{4}$ Osoby odwiedzające moga jedynie utożyć kamyki w miejscach spoczynku bliskich.
25 Muzeum Stacja Radegast. Oddziat Muzeum Tradyci Niepodlegtościowych
${ }^{6}$ Autor: Crestaw Bielecki, 2006 h

Wedtug przykłádów wy bronych przez autorke.

LITERATURA

[1] Batuty legenda i rzeczywistość, pod red. Marcina J. Szymańskiego,
Wyd.1, todż, KSIEZZY MLYN Dom Wydawniczy, 2017, ISBN 978-83-

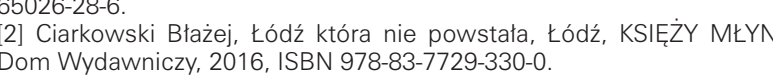

elements of a "green", repeating motif, which constitutes time, the backstch for

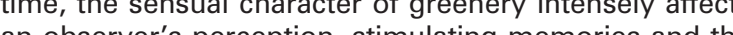
of the Skin:

Perception, memory and imagination are in a state of ceaseless interaction.

ENDNOTES

"From 1244 ha before 1821 to 2736 ha in 1840

establishment of the Łẹczyca - Piotrków trail, which divided Batuty nto two parts, and wich wilsz wer connect with the so-called Factory trail, connecting Kalisz with Eowicz through tódź and
Zgierz. A tram line was built in 1912 along the line of the factory tral (Aleksandrow's Road).
3 Zakklad Osiedli Robotniczych - Workers' Housing Section.

'Zaklad Osiedli Robotniczych - Workers' Housing Section.
4 The design of the Community Centre by dozef Zbigniew polak of
1951 was built in Rzeszów. Today it houses the Faculty of Music of the University of Rzeszów. rabbinic court.
"Beron + Rojal „Batucka krew"; source: https://www.youtube.com watch? ? =4 Kinl "LpuM. [retrieved on 1503.2018].

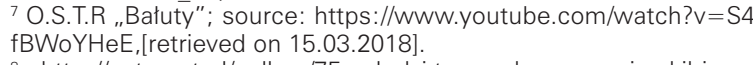

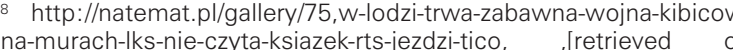

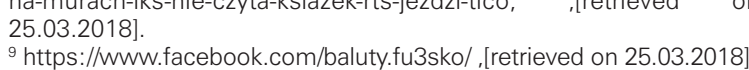

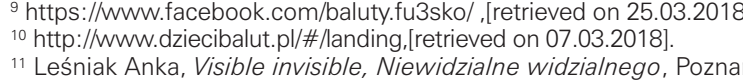
Stowarzyszenie Publish Art, 2017.

e design: Kazimierz Chrabelski. 1953

Author of the sculpture: Gustaw Zemta. 1995.
14 According to the author, a memorial site is any transmission of the past into the present that we can place within space.
i5 Do not lose heart (Rachmil Bryks, The tódź Ghetto, 1940 )

It's just the wind blowing--
Do not lose heart my child.
We are old trees,

Rooted deeply and broadly in the earth,
With great crowns that decorate the world

Strong storm winds can
Tear away our leaves,

Break our branches,
But not the crowns:

Strong, deeply rooted trees

Winds cannot tear away

Nor uproot!
We are eternal tre
Wiving herry frut to

Giving hearty fruit to the world

We will be eternal!
It's just the wind lowing
Do not lose heart my chi

https://www.centrumdialogu.com/park-ocalalych/biogram 17 https://www.centrumdialogul.com/park-ocalalych, [retrieved on ${ }_{18}$.

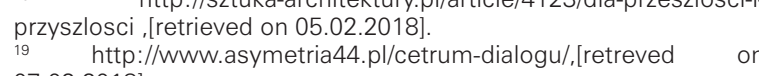
${ }^{20} \mathrm{http}: / / /$ szlaki.pttk.pl//odzkie//007.html, [retrieved on 06.02.2018]. ${ }_{21}^{2}$ http://www.zielonalodz.pl/parki.php? park=szarychszeregow, [ret

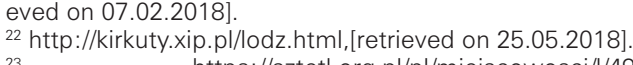

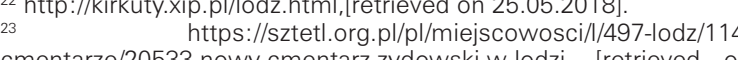
$24.05 .2018]$.
24 Vistors ore only allowed to place small pebbles on the places of ${ }^{24}$ Visitors are only allowed to place smal pes their loved ones.
rest Independence Traditions.
${ }_{20}$ Author: Crestaw Bielecki, 2006.

${ }^{27}$ According to examples selected by the author

Bibliography:

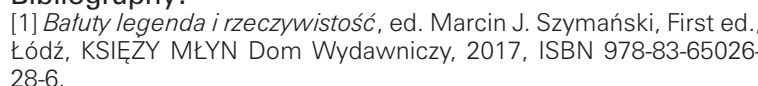

[3] Leśniak Anka, Visible invisible, Niewidzialne widzzialnego, Poznan
Stowarzyszenie Publish Art, 2017, ISBN 978-83-941932-1-8.

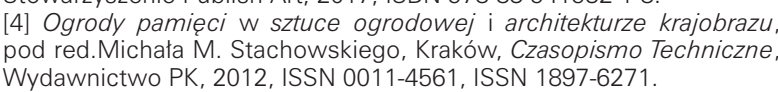

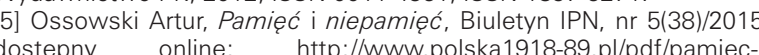

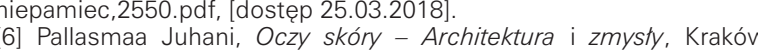
7] Rawluk Maciej, Batuty-palimpsest, tódż, ByłoBędzie, 2015, IS 8] Saryusz-Woiska Magdalena, Spotkania czasu z miejscem. Stud pamieci i miastach, Warszawa, Wydawnictwa Uniwersytely
Warszawskiego 2011 ISBN $978-83-235-0741-3$

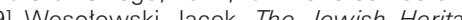

Heritage in the urban space of

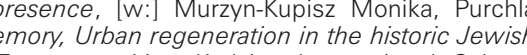
quarters of Central European cities, Kraków, International Cultura [10] Wycichowska Barbara, Park Ocalatych w todzi. Wspótczesn offiarach tódzkiego getta, [W:] Czasopismo techniczne, Wydawnictwo PK, 2010, ISSN 1897-627.

[11] http:///kirkuty.xip.pl/index.htm, [dostęp 06.02.2018]. [dostep $131 \mathrm{http}: / / \mathrm{w} w$ w. muzeumtradycij.p/3-historia/, [dostepp 07.02.2018.

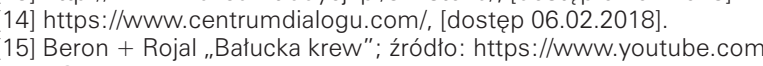

16. O.S.T.R. .Băłuty"; źródło: https:I//www.youtube.com/watch?v=S4 [17] http://natemat.pl/gallery/75,W-lodzi-trwa-zabawna-wojna-kibicow18] https://Www.facebook.com/baluluty.fu3skoo/, [dostep 25.03.2018].

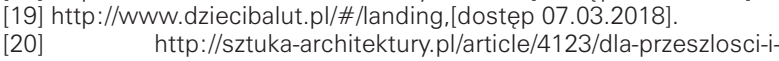
hetp://sztuka-arch
przyszlosci, dostep 05.02.2018]

[21] hitp://Www.asymetria44.p//cetrum-dialogu//[dostep 07.02.2018] 23] http://Www zielonalodz p/parki php? park=szarychszeregow, Idost [20 07.02.2018]. hitps://sztett.org.pl/pl/miejscowosci//497-lodz/114 cmentarze/20533-nowy-cmentarz-zydowski-w-lodzi, [dostę
25.05.2018].

SPIS ILUSTRACJ:

1,2 - https:///l. wikipedia.org/wiki/Park_Staromiejski_w_\%C5\%81 odzi 3.6,9, 12,15- schematy autorki.
[2] Ciarkowski Btazej, tódź Która nie powstała, Lódź, KSIEZZZY MLYN B] Leśniak Anka Visible invisible Niewidzalne Slowarzyszenie Publish Art, 2017, ISBN 978-83-941932-18. [4] Ogrody pamiecci w sztuce ogrodowej i architekturze krajobrazu,
ed..Michat M. Stachowski, Kraków, Czasopismo Techniczne,

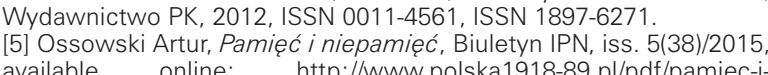
niepamiec,2550.pdf, [retrieved on: 25.03.2018].
6) Pallasmaa Juhani, Oczy skón'y - Architektura i zmysly, Kraków, 6] Pallasmaa Juhani, OCZy skón - Architektura I zmysty, Krakó [7] Rawluk Maciej, Batuty-palimpsest, Łódź, ByłoBędzie,2015,IS

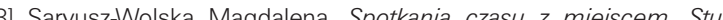
o. pamieci i miastach, Warszawa, Wydawnictwa Universytetu

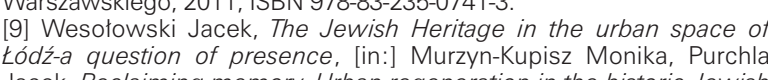

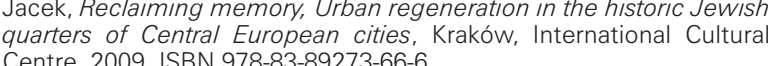

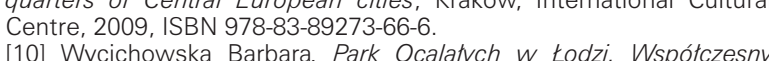

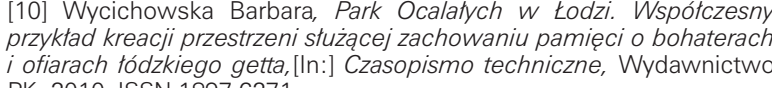
[11] http://kirkuty.xip. pl/index.htm, [retrieved on 0602 2018)

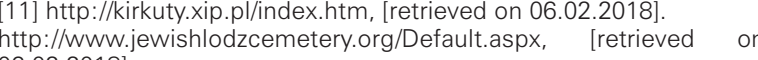
06.02.2018].

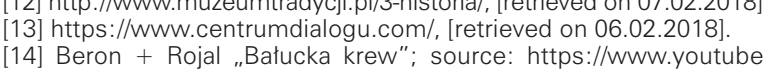

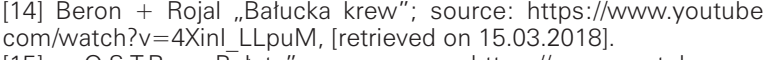
[15] O.S.T.R "Beatuty"; $;$ source: https://Mw

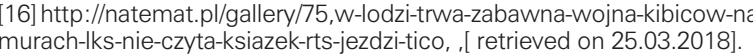
[17] https://www.facebook.com/baluty.fu3sko/, i retrieved on

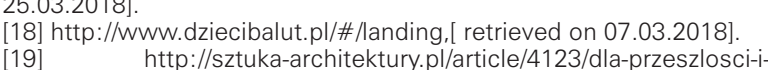

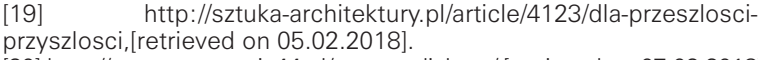

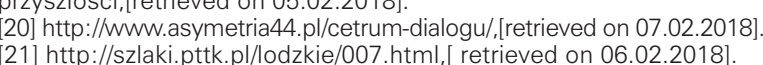

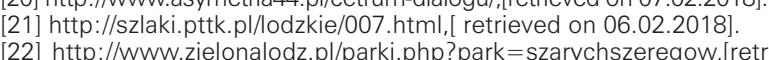
ieved on 07.02 .2018 .

23] https://sztett.org.pl/p///miejscowoscii//497-lodz/114-cmentarze/20533-

\section{TABLE OF ILLUSTRATIONS}

1,2 - https://pit.Wikipedia.org/wiki/Park Staromiejski W_\%C5\%810dz

$3,6,9,12,15-$ original schemes,
$4,5,7,8,10,11,13,14-$ phot. by Matgorzata Petelenz, 2017 